\begin{tabular}{lcc}
\hline & ANNALES \\
& & \\
UNIVERSITATIS MARIAE CURIE-SKLODOWSKA & \\
LOL.I & SECTIO M & 2016 \\
\hline
\end{tabular}

Jacek Wojnicki

University of Warsaw

\title{
The Formation of the Party System in the Republic of Macedonia
}

\section{The bases of functioning of legal political parties}

The Constitution of Macedonia includes political pluralism and direct and free election for fundamental value of constitutional order of the Republic (Article 8 of the Constitution) ${ }^{1}$.Fundamental act guarantees freedom of banding for realisation political, economic, social, cultural law and other laws and convictions (Article 20 of the Constitution). Citizens of the republic can build civil union and political parties with an easy manner, they can join the party and resign from it. The constitution stipulates simultaneously that programs and activity of civil union and political parties cannot measure for infringement violence of the constitutional order of the republic, preparation of war aggressions either calling for such aggression (Article 8 of the Constitution).

In programs of the political parties it was forbidden to spread ideas of hatred or national, racial or religious intolerance. A fundamental act bans creation of paramilitary department, which do not enter the composition of military power of the Republic of Macedonia (Article 20 of the Constitution). The Constitution bans also creation and functioning of a political party in jurisdiction, military power. Above-mentioned constitutional regulations are distinct breaking with practice of functioning communist party in socialist Yugoslavia (in union republics as well).

1 J. Jackowicz, Wprowadzenie, [in:] Konstytucja Republiki Macedonii, Wydawnictwo Sejmowe, Warszawa 1999, p. 21. 
The act from 28 June 1994 on political parties is legal base in the Republic of Macedonia ${ }^{2}$ defining functioning of political organizations. Above-mentioned act defines principles of creation, sponsorship and liquidating of a political party. Foundation of a political party belongs to a group of 500 citizens who have electoral rights. A group is placed in special register, not later than 15 days before an end of current year, register leads district court in Skopje. Founders of political parties are obliged within 30 days from initiator's assembly to inform the district court about this fact.

The Court has 15 days for the ruling, whether the removed charter can be accepted or it requires removal of legal lapse. The Court gives 30 days for the action. Founders of parties present to the Court the name of party and list of its founders which are obliged to be permanent residents. Functioning of a political party is based on charter of group (rules and regulations). It defines program purposes of parties, principles of reception of new members, organization of internal group, principles of sponsorship, as well as liquidation procedure. Symbols and name of a political party must differ from names and symbols other political group (either in Macedonia or any other foreign country) ${ }^{3}$.

The activity of a political group undergoes solution in several cases. The first situation presents the prohibition of activity of a political party by the conversant court. The second case presents judgement of Constitutional Tribunal about incompatibility of a program or a charter of a party with fundamental act. The third situation takes place in case of taking of decision of self-dissolution, by an executive organ of a political party, however, fourth - when number of members of group will fall below 500. Municipal court takes decision of delegalisation of a political group, however, above-mentioned judgement can become sue for district court in Skopje. This court has 8 days to respond to the complaints ${ }^{4}$.

The decision on the registration or dissolution of a political party shall be published in the Official Gazette of the Republic of Macedonia ("Služben Vestnik Makedonija"). The legislator also lists the acceptable sources of financing political parties, inter alia: membership fees, contributions of private persons, donations, credits, decreases and center from central budget. Problems of functioning political stages of the Republic of Macedonia have been regulated by the first legal act on social organisations and civil associations accepted by the Sobranie in April 1990 ${ }^{5}$. Above-mentioned legal act allowed registration the

\footnotetext{
2 “Služben Vesnik na RM", 1994, no. 41.

3 P. Rzegocki, Macedonia, [in:] Partie i systemy partyjne państw Europy Środkowej $i$ Wschodniej, ed. M. Migalski, Wydawnictwo Wyższej Szkoły Zarządzania i Marketingu, Sosnowiec 2005, p. 204.

4 Ibidem.

5 Ibidem, p. 203.
} 
political group functioning in semi-legal conditions. The next step in direction of democratisation of a political system of the republic was the decision of authority about conducting of a multiparty election for parliament in November 1990.

\section{Multiparty system revolt. Electoral rivalry in 1990}

After 1945, when Yugoslavian federation was build, Macedonian Republic has entered into its composition. The Communist Party of Macedonia was a sole legal political party until 1990 (from 1952 as an Association of Communist of Macedonia - Komunistička Partija Makedonije - Sojuz Komuniste Makedonije). It entered as a republican organization to composition of Communist Party of Yugoslavia (the next name: Assiociation of Communist of Yugoslavia) (Komunistička Partija Jugoslavije). The most eminent communist politicians in Macedonia were Lazar Koliševski, Lazar Mojsov and Alexander Grličkov ${ }^{6}$.

The last communist authorities, in which predominating position Kiro Gligorov has occupied, decided to opening door towards political pluralism 7 . New political parties emerged fairly quickly ${ }^{8}$. In the initial period they were registered on base on act of 1 April 1990 on social organizations and civil associations. However, on 28 June 1994 the parliament voted the act on political parties ultimately. Among new created groups one should mention Internal Macedonian Revolutionary Organization - Democratic Party of National Unity (VnatrešnoMakedonska Revolucionerna Organizacia - Demokratska Partija Makedonsko Narodno Edinstvo - VMRO - DPMNE). Its founders tried to refer to organization conflicting about independence of Macedonia at the turn of $19^{\text {th }}$ and $20^{\text {th }}$ centuries. The head of anticommunist movement in the Republic was Dragan Bogdanovski. He issued emigration magazine "Makedonskata nacija" in the mid-80s of the $20^{\text {th }}$ century ${ }^{9}$. Ethnic groups represented emerged interests of Albanian minorities - most important e.g. Party of Democratic Development (also Partija Demokratski Prosperitet - PDP).

6 See: I. Stawowy-Kawka, Historia Macedonii, Zakład Narodowy im. Ossolińskich, Wrocław 2000, p. 277 and next. See also P. Olszewski, Macedonia. Historia i wspótczesność, Wyższa Szkoła Handlowa, Radom 2010, p. 86 and next.

7 See: D. Perry, The Republic of Macedonia: finding its way, [in:] Politics, power and struggle for democracy in South-East Europe, eds. K. Dawisha, B. Parrott, Cambridge University Press, Cambridge-New York 1997, p. 233.

8 See: Z. T. Irwin, Macedonia po 1989 roku, [in:] Polityka Europy Środkowej i PołudniowoWschodniej po 1989 roku, ed. S. P. Ramet, Książka i Wiedza, Warszawa 2012, p. 366 and next.

9 See: I. Stawowy-Kawka, op. cit., p. 280 and next; New political parties of Eastern Europe and the Soviet Union, ed. B. Szajkowski, Harlow-Essex 1991, p. 304 and next. 
Contemporary chief of Yugoslavian government Ante Marković was disturbed bt the enhancement of influence of the nationalistic group in the Republic. He decided to establish a Yugoslav-oriented party focused on economic and political reforms. In 1990, he formed the Alliance of Reform Forces of Yugoslavia (ARFY) (in Serbian: Savez Reformskih Snaga Jugoslavije). He expected to gain electoral support thenjs to his personal and his Government's popularity but also support by Yugoslav-oriented voters. Elections in Macedonia were supposed to be the test of popularity for Ante Marković and his party.

Table 1

The political parties created in Macedonia in 1990

\begin{tabular}{|c|c|c|c|c|}
\hline & Name & Seat & Origin & Registration \\
\hline 1 & $\begin{array}{l}\text { Movement for Macedonian Action } \\
\text { (MAAK) }\end{array}$ & Skopje & 4 February 1990 & 12 June 1990 \\
\hline 2 & Democratic League & Skopje & 11 February 1990 & 8 June 1990 \\
\hline 3 & Worker Party in Macedonia & Prilep & 4 March 1990 & 12 July 1990 \\
\hline 4 & Social Democratic Party of Macedonia & Skopje & 18 March 1990 & 25 May 1990 \\
\hline 5 & National Party of Macedonia & Skopje & 12 April 1990 & 2 June 1990 \\
\hline 6 & Democratic Prosperity Party & Skopje & 15 April 1990 & 25 May 1990 \\
\hline 7 & Democratic Alliance - Peasant Party & Strumica & 15 April 1990 & 8 June 1990 \\
\hline 8 & People’s Democratic Party & Tetowo & 23 April 1990 & 1 August 1990 \\
\hline 9 & Democratic Party & Ochryd & 9 June 1990 & \\
\hline 10 & VMRO - Party of National Unity & Skopje & 17 June 1990 & 3 August 1990 \\
\hline 11 & Worker Party & Skopje & 24 June 1990 & 3 August 1990 \\
\hline 12 & $\begin{array}{l}\text { SKM - Party of Democratic Trans- } \\
\text { formation }\end{array}$ & Skopje & & 3 August 1990 \\
\hline 13 & Young Party of Democratic Progress & Skopje & 12 July 1990 & 24 August 1990 \\
\hline 14 & Party of Socialists of Macedonia & Skopje & 13 July 1990 & 24 September 1990 \\
\hline 15 & Party for Human Rights & Strumica & 20 July 1990 & \\
\hline 16 & Yugoslave Party & Skopje & 26 May 1990 & 17 July 1990 \\
\hline 17 & Party of Full Emancipation of Rom & Skopje & 20 August 1990 & 29 August 1990 \\
\hline 18 & Political Party of Unemployment & Prilep & & 12 September 1990 \\
\hline 19 & Worker and Peasant Party & Skopje & 15 September 1990 & 16 October 1990 \\
\hline 20 & Turkish Democratic Alliance & Skopje & 22 September 1990 & \\
\hline 21 & Alliance of Democratic Force & Skopje & 15 September 1990 & 16 October 1990 \\
\hline 22 & Democratic Union & Skopje & 15 November 1990 & \\
\hline 23 & $\begin{array}{l}\text { Balkan Federation - Balkan without } \\
\text { Borders }\end{array}$ & Skopje & & 15 December 1990 \\
\hline
\end{tabular}

Source: M. Ristovska, Mnizinskiot i proporcjonałniot modeł na raspredełba na prateničkite mesta vo Sobranieto na Republika Makedonija vo 1990, 1994 i 1998 godina, doctorate of Law Department in University St. Cyril and Methodius, Skopje 2004, p. 191. 
The first multiparty election in Macedonia took place on 11 and 25 November $1990^{10}$. Elections of 9 November 1990 were repeated on 25 November 1990 in 176 districts, due to various kinds of formal irregularities. The second round took place on 9 December 1990. In the election, 18 parties and political groups participated. Internal Macedonian Revolutionary Organization - Democratic Party of National Unity (VMRO-DPMNE) got maximally 37 credentials. The next 31 deputies represented so far ruling communist, which have approached for election under the new name - Association of Communist of Macedonia - Party Democratic Conversion (Sojuz Komuniste Makedonija - Partija Demokratska Preobrazba - SKM-PDP). However, Albanian Party of Democratic Welfare was the third parliamentary group (Party Prosperitet per Demokratik - PDP) (25). Ante Marković gained high support winning 19 seats.

Table 2

The result of elections in Macedonia (11 XI and 25 XI 1990)

\begin{tabular}{|l|c|c|}
\hline \multicolumn{1}{|c|}{ Parties } & Votes & Deputies \\
\hline VMRO-DPMNE & 24,3 & 38 \\
\hline SKM-PDP & 25,3 & 31 \\
\hline PDP & 23,5 & 25 \\
\hline SRSM & 18,1 & 19 \\
\hline SPM & 4,7 & 4 \\
\hline NDP & 0,4 & 1 \\
\hline others & - & 2 \\
\hline
\end{tabular}

Source: self-made.

3. Formation of the political stage in Macedonia

Social Democratic Association of Macedonia is the main leftist group in Macedonia (Socijaldemokratski Sojuz Makedonija - SDSM). The party was established due to internal transformation of the Macedonian communist party. In November 1989, the Tenth Convention of the Macedonian Communist League took place where Petar Grošev was elected as a new leader. The process of transformation of the communist party started being patronised by the President Kiro Gligorov and resulted in emergence of three political parties. Therefore,

10 A. Koseski, Główne problemy transformacji w Republice Macedonii (1991-2000), [in:] Transformacja systemowa państw Europy Wschodniej, Środkowej i Południowej, eds. T. Godlewski, A. Koseski, K.A. Wojtaszczyk, Wyższa Szkoła Humanistyczna im. Aleksandra Gieysztora, Pułtusk 2003, p. 156 and next. 
the Alliance for Macedonia in the election of November 1994 consisted of social democrats, socialists and liberals ${ }^{11}$.

Established in April 1991 Social Democratic Association of Macedonia was a left-wing party with Branko Crvenkovski as its leader. He fulfilled functions of party chiefs until 2004, when he was chosen the president of the Republic. Vlado Bučkovski was a new leader elected in November 2004. This party was a successor of the Macedonian Communist League gathering the most of the apparatus of the old party that accepted the values of free market and democratic values. Social democrats built ruling coalitions during 1992-1998 and from 2002 until 2006. After lost elections in 2006, old authorities resigned and the extraordinary congress decided on a new party leader - Radmila Szekerinska. General Secretary of the congress has been Goran Minčev, vice-chairmen were Yan Makraduli, Igor Ivanovski and Zoran Zajev.

The second leftist group -Socialist Party Macedonia (Socialistička Partija Makedonija - SPM) emerged from transformation of mass organization - Socialist Association of Working People Macedonia (SZLPM) ${ }^{12}$. The first leader of the group was Kiro Popovski, the next Ljubislav Ivanov-Zingo. The party announced the necessity for gradual social-market reform and taking into consideration social justice, it criticized the process of privatization of state property. The biggest success was participation in wide center-left coalition in election in 1994 (8 credentials in Sobranije and it entered the government of Branko Crvenkovski). During 1992-1998, SPM entered the centre-left ruling coalition. Then, from 1998, the party has remained in opposition to centralrightist government VMRO-DPMNE. The authorities of the groups in 2002 have declined approaching for wide centre-left coalition under direction SDSM. In 2003 socialists built a coalition including two smaller parties: Democratic Alternative and Democratic Union. During election in 2006 they entered the composition of electoral coalition by VMRO and LPM and 11 small parties. SPM earned 3 credentials in the parliament and participated in the government of Nikola Gruevski.

The third organization - Liberal Party (Liberal Partija - LP) emerged as a Macedonian branch of Association of Reformatory Power, political platforms appointed by the last prime minister of Yugoslavian federation Ante Marković. The party announced the necessity for gradual social-market reform and transformations of Yugoslav federation. The leaders of the groups were Stojan Andov

11 See: J. Darski, Macedonia - oaza komunistów i pokoju, http://republika.pl, access: 15 XI 2013.

12 See: Osnowanije i razwoj SPM, http://www.spm.com.mk, access: 15 XI 2013. 
and Risto Ivanov. The party became a central figure at the Macedonian political scene being able to take part also in centre-leftist as well as central-rightist electoral and government coalitions ${ }^{13}$.

Internal Macedonian Revolutionary Organization - Democratic Party of National Unity (Vnatrešno-Makedonska Revolucionerna Organizacja - Demokratska Partija Makedonsko Narodno Edinstvo - VMRO-DPMNE) plays an important role in a party system of Macedonia as the first group proceeding in the early 1990s of $20^{\text {th }}$ century which aimed at gaining Macedonia's independence. The organization's name referred to VMRO group combating for free Macedonian state from the end of the 19 century. During the years of communist governments 105 hidden groups acted, by political police subjected repressions, counting 1,200 members ${ }^{14}$. The party proceeded transformation in economic sphere from etatism to acceptance of free-market economy. It supports privatisation and expression of estate former owners. In the program of organization one may find the record about reintegration of Islamic Macedonian. VMRO-DPMNE declared support for Macedonians living outside of the Republic. However, it gave away ideas of regaining all-Macedonian lands which was an official standpoint in the the early 1990 s of the $20^{\text {th }}$ century.

The structure of VMRO is based on local circles, the next municipal committees act in cities, district committees with 85 constituencies for parliament and central committee. Congress, being the highest authority in the group, usually elected every 4 years. The congress accepts most important program documents and it chooses head of party. Current management of party falls within the competence of an 11 -person executive committee.

The first leader of VMRO (after 1990) was Ljupčo Georgievski. The leaders of the group since 2003 were: Nikola Gruevski, deputy Trajko Slavevski and general secretary Gordana Jakulovska. The group has won first multiparty election in November 1990 (24.8\%), boycotted in 1994 but gained 28.1\% in the 1998 elections. Then VMRO built ruling coalition with Democratic Alternative DA and Albanian DPA. One ought to mention that the candidate of VMRO Boris Trajkovski in 1999 won in the second round presidential election (got over 52\% of votes). VMRO became the main opposition group after election in 2002 relatively to social democratic cabinet (24.4\%). The group won the next election in September 2006 (32.5\%) and the leader of the group Nikola Gruevski built government on the base of central-rightist coalition.

13 See: Istorijat na Liberalnata Partija na Makedonija, http:// www.liberalna.org.mk, access: 15 XI 2013.

14 See: J. Bugajski, Ethnic politics..., p. 111 and next. 
The Liberal Party of Macedonia (Liberal Partija Makedonija - LPM) is a centrist political party ${ }^{15}$. The party focuses mainly on ethnic Macedonians, supporting free-market economy, privatisation and parliamentary democracy. The party was created in October 1990 from transforming structure of Association of Reformatory Power. In 1994, the party entered into coalition with social democrats and it participated in government of Branko Crvenkovski. It left ruling coalition in 1996 and it was put together with Democratic Party (Demokratska Partija) building Party Liberal Democratic (Liberalno-Demokratska Partija - LDP) ${ }^{16}$.

The official cause of the conflict were the demands of ministers from the Liberal Party to remain as experts which would indemnify them against effects of the Government's actions. When the idea of electoral coalition with social democrats appeared in the new party, the founders of the liberal party decided to revive the old party. The Congress of Liberal Party took place in December 1999 and a new leader was elected - Risto Guszterov. In 2000, the party group independently started in local election (getting 40 seats in municipal councils) and joined the ruling coalition with VMRO and DPA which basically saved the Cabinet of Ljupčo Georgievski from dismissal. The party signed a document of strategic coalition with VMRO in 2004, declaring common participation in the next election for assembly. During 17 years of existence the party had: 58 deputies, 12 ministers, 3 vice-prime ministers and 4 ambassadors. However, in electoral coalition in 2006 elections with LDP SDSM it gained 12 seats.

A long-term party leader 1991-1996 was Stojan Andov (2000-2002 being head of parliament). He was the leader of the group in two phases of existence of the parties during 1990-1997 and from $2001 \mathrm{on}$. The best electoral results of party was in 1994, when it got $24.1 \%$ (boycotted by VMRO), and in $1998-7.0 \%$. Democratic Alternative has emerged in the center of political stage (Demokratska Alternativa-DA). The party was established in 1998 by charismatic Vasil Tupurkovski, called Balkan's Kissinger due to his participation in the 1990 talks on the future of Yugoslav federation. The group declared themselves as social-liberal, with enhancement of active role of state in problems of social insurances. It participated in a coalition with VMRO in 1998 winning 13 seats. Until November 2000 the group participated in the Ljupčo Georgievski government, then left the centre-rightist coalition. The party emerged as a political platform for Vasil

15 See: Istorijat na Liberalnata Partija na Makedonija, http://www.liberalna.org.mk, access: 15 VI 2016; J. Bugajski, Political Parties of Eastern Europe. A Guide to Politics in the PostCommunist Era, New York 2002, p. 742.

16 J. Jackowicz, Macedonia, p. 145; idem, Macedonia, "Europa Środkowo-Wschodnia", 1996, no. 6, p. 147. 
Tupurkovski candidacy in presidential election in 1999. But it was a spectacular defeat for Tupurkovski.

The problem of Albanian minority plays significant role in Macedonia. It presents about $25 \%$ inhabitants of the Republic ${ }^{17}$. The fragile ethnic structure in Macedonia enabled acts of terror provoked by Albanians through their so-called Liberal Army of Kosovo (UÇK). This organization organized military provocations on the Macedonia-Kosovo borders. The situation became very tense in spring of 2001, so, it resulted in bloody battles of Macedonian troops with Albanian rebels. Diplomatic intervention of American politicians and European active stance through KFOR helped stabilizing the situation ${ }^{18}$. Albanians have built several political groups representing their social-economic interests. The party of Democratic Welfare is one of the most important parties (Partija Demokratski Prosperitet - PDP), taking part in consecutive parliamentary election beginning from $1990^{19}$. It participated in the next government cabinets built with social democrats and VMRO-DPMNE. It followed in 1998 in PDP. The part of politicians of this group built a competitive organization - Party Democratic Welfare Albanian (Partija za Demokratski Prosperitet Albacite PDPA). Arben Xhaferi became the leader of the organization. The party opted to Macedonian federalization and it aimed at recognition of Albania for the second (other) state nationality. The democratic union of integration emerged before the next election in 2002 (Demokratska Unija Integracija - DUI) and Ali Ahmeti - the former leader of Army of National Liberation (UÇK) - became its new political leader. A new party declared a programme which set up realization of the Ochrid Agreement from July 2001 and the battle with corruption. Immediately this group pushed the rests of Albanian parties into the shadow. Ahmeti was perceived as someone who struggled for the rights for Albanians, however, PDP and PDPA were considered corrupted. DUI won 16 seats in the September 2002 parliamentary elections winning the third place after socialdemocrats and $\mathrm{VMRO}^{20}$.

There are two new political parties at the Macedonian political scene emerged from VMRO and Socialdemocrats: the National Party (Partija Narodna

17 See: A. Balcer, Albańska kwestia narodowa, [in:] Konflikty etniczne w Europie Środkowej i Potudniowo-Wschodniej, "Zeszyt OSW", 2002, no. 6, p. 16 and next.

18 See: A. Koseski, Macedonia: od republiki zwiazkowej do państwa unitarnego, [in:] W batkańskim kręgu, Akademia Humanistyczna im. Aleksandra Gieysztora, Oficyna Wydawnicza Aspra-JR, Pułtusk-Warszawa 2013, p. 158.

19 See: A.M. Polkowska, Macedonia, Agencja Wydawniczo-Reklamowa Alta 2, Wrocław 2000, p. 33.

20 See: A. Burakowski, Macedonia, "Europa Środkowo-Wschodnia”, 2001-2002, no. 11-12, p. $156,433$. 
- VMRO-NP) and new social democracy (Nova Socijaldemokratska Partija NSDP). The leaders of the first parties were Vesna Janevska (before 2007) and Dżordżi Trendafilov (after 2007). The leader of the New Social Democracy was Sonja Mirakovska. The national party is a conservative group built (created) in July by apologists of first leaders of 2004 VMRO Ljupčo Georgievski. However, the new one was built (created) in 2005 by secessionist from SDSM Tito Petkovski. The National party won 6 seats in election to assembly in 2006 with 6.1\%, new leftist party-about 6\% (7 seats). It is hard to say whether these parties won a permanent place at the political scene. June 2008 elections showed that none of them won any seats in the parliament.

Local elections in March and April 2005 were a test of popularity for political parties in Macedonia. It confirmed a strong position of VMRO-DPMNE as a major opposition party. Candidates won in 21 borough out of 84. In Skopje, Tifun Kostovski was supported by VMRO. However, a small support for Ljupčo Georgievski of VMRO-National Party gave major position only in three municipalities. The party split has had also its ideological roots. Nikola Gruevski wished to transform VMRO into a western-style Christian Democracy party. Georgijevski prefered the "Balkan style" leadership in the party based on a oneman leadership ${ }^{21}$.

After winning the September 2006 elections by the centre-rightist parties, the VMRO fraction of Nikola Gruevski gained 44 seats and Ljupčo Georgievski's party 7 seats. Gruevski won a vote of confidence by 68 MPs. In return for the support of the Government People's Party leader Georgijewski was elected the chairman of the Assembly. After winning 11 seats Arben Xhaferi's Albanian Democratic party also became a member of the coalition. This was a consolidation of Macedonian and Albanian right-wing parties and reestablishment of the coalition which was in power between 1998 and 2001, when military clashes with Albania's minority took place ${ }^{22}$.

In order to determine the origin of political parties one can come to the conclusion that there are four types of them: historical parties (emerged in the Turkish times, illegal either in Monarchist and Socialist Yugoslavia) - VMRO; post-communist parties (transformed from the Communist party of Socialist Yugoslavia) - SKM-PDP, SDSM, SSM; ethnic Albanian parties groups (PDP, DUI, PDPA), and so called new parties focusing on various aspects - social, religious if ecological - of public life - LDP, DA ${ }^{23}$.

21 See P. Codogni, Macedonia, "Europa Środkowo-Wschodnia”, 2005, no. 15, p. 175.

22 J. Darski, Prawica w Macedonii, "Gazeta Polska”, 25 X 2006, no. 43.

23 P. Rzegocki, op. cit., p. 205. 
4. Election for the assembly in June 2008

The political crisis in April was the result of lack of invitation for the Republic of Macedonia for North Atlantic Treaty Organisation in 2008. It did not take part in the summit in Bucharest regarding membership of Macedonia by reason of objection of Greece NATO decision holding. Macedonian delegation had announced (as a sign of protest) that it would leave from summit earlier. The chief of Macedonian diplomacy explained that it was obliged to take into consideration the fact of support for NATO by over $90 \%$ of the society.

The Greece's objections concern the official name of the Republic as it refers to ancient Macedonia ${ }^{24}$. The March survey shows that over $80 \%$ of Macedonians expressed readiness to resign from NATO membership if this would mean resignation from the official name of the Republic ${ }^{25}$.

Voting in the early elections to the Assembly took place in the shadow of ethnic clashes. The result of shootings was one person killed, 9 injured and 13 arrested. For safety reasons, the election vote was interrupted in at least 20 polling stations. Incidents took place in the north-western parts of the Republic inhabited by Albanian minority. The European Commission expressed concerns about the acts of violence. At the same time, the Commission reminded the authorities in Skopje that fair elections are an important test to prove that they belong to the European institutions ${ }^{26}$.

The centre-rightist coalition "For better Macedonia" established by Nikola Gruevski has won the elections. Overwhelming victory (48.24\%) could secure a stable political majority with a priority in integration with the EU and NATO. However, ethnic clashes caused by Albanians could be a serious problem for this process. The early elections were caused by the Macedonian diplomacy defeat during the NATO summit in Bucharest and with internal conflict within the ruling coalition VMRO-DPMNE and Albanian Democratic Party (PDSh). It concerned a conflict over the status of Albanian minority. The elections were to be the test of popularity for the centre-rightist cabinet of Nikola Gruevski. It gained large support within Macedonian population (over 60\%) due to hard-line position in talks with Greece over the name issue. Also, the support was due to consequently undertaken reforms and unyielding policy towards Albanian

24 J. Pawlicki, A. Skieterska, NATO dla Afganistanu, "Gazeta Wyborcza", 4 VI 2008, D. Pszczółkowska, Kolejka do NATO jeszcze postoi, "Gazeta Wyborcza”, 7 III 2008.

25 Macedonia gotowa jest polec za swa nazwę, "Dziennik”, 11 III 2008, T. Stylińska, Macedonia czy greckie gadanie, "Tygodnik Powszechny", 6 IV 2008, no. 14.

26 Macedonia. Wybory do nowego parlamentu w cieniu starć etnicznych, "Dziennik", 2 VI 2008, A. Skieterska, Wyborcza przemoc w Macedonii, "Gazeta Wyborcza”, 2 VI 2008. 
minority. Social democratic coalition won the second place "The Sun - Coalition for Europe" being a part of the Macedonian Social Democratic Alliance (23.31\%). Two Albanian parties - Albanian Democratic Party (10.52\%) and Democratic Union for the Integration (11.13\%) were next in a row ${ }^{27}$.

Nikola Gruevski's party signed a coalition agreement (as a result of a several weeks negotiations) with the biggest Albanian minority party - Democratic Union for the Integration) (DUI). This was one of the parties that organised a military uprising in 2001 against the Macedonian authorities. Although Gruevski had an overwhelming majority in Assembly, he aimed to assure wider support for his government with almost $25 \%$ of Albanians supporting the Albanian parties ${ }^{28}$.

\section{Elections in June 2011}

The turning point in Macedonia's social and political life occured in December 2010 when V. Ramkovski, a media potentate, was arrested. The Skopje Court has accused him with criminal charges. Arrest of Ramkovski's closest colleagues launched protests of many journalists who were afraid of losing their jobs in private medias ${ }^{29}$. Political crisis has increased in parliament in January 2011 year, when politicians of biggest opposition parties have decided on boycott of work of assembly - SDSM.

Parliamentarians of the Left accused the Nikola Gruevski's government of being restrictive when it comes to civil freedoms. They also accused him of growing economic crisis and worsening relations with Greece. This was strictly related to a lack of any improvements when it comes to the integration processes with NATO and the European Union. Government took negotiations with social democrats in relation to interrupt a boycott of work of parliament, but without expected results. So, the management of the party decided to prepare about conclusion ruling assembly term VMRO-DPMNE self-dissolution. The early elections' goal was not only the end of this political crisis but also confirmed popularity of the Nikola Gruevski's government. The $15^{\text {th }}$ of April 2011 assembly voted a self-dissolution act, supported by VMRO-DPMNE and Albanian representatives ${ }^{30}$.

27 M. Szpala, Wybory parlamentarne w Macedonii, “BEST OSW. Tygodnik OSW”, 4 VI 2008, no. 53.

28 Umowa koalicyjna w Macedonii, "Dziennik", 7 VII 2008.

29 See: P. Żukiewicz, Przedterminowe wybory w Macedonii w 2011 r. i ich skutki dla konfiguracji macedońskiego systemu partyjnego, "Przegląd Prawa Konstytucyjnego", 2012, no. 2 (10), p. 82.

30 Analizy OSW: Rozpisano wybory przedterminowe w Macedonii, www.osw.waw.pl, access: 15 XI 2013. 
The parliamentary election took place on 5 June 2011 and brought victory to VMRO-DPMNE and Albanian member of coalition - BDI. However, the support to the parties dropped by $1 / 5$ compared to the 2008 elections. The success of the Albanian party was a message for the continuation of the coalition. The elections ended the political crises and confirmed the support for central-rightist government directed by Nikola Gruevski. Socially oriented parties also gained some support ${ }^{31}$. The elections brought the following results: VMRO-DPMNE 39\% (56 seats), SDSM - 32.8\% (42 seats), Albanian BDI - 10.2\% (15 seats), PDSh - 9\% (8 seats) and National Democratic Revival (RDK) - 2.7\% (2 seats). They have formed the VMRO-DPMNE and BDI coalition with its leader Nikola Gruevski who took position of a prime minister again.

\section{Conclusions}

The party system in Macedonia is a type of a polarised multiparty system. Two groups play a key role in party system (SDSM and VMRO), however, wide coalitions are built in order to strengthen their positions on the political scene, centre-left (casus SDSM), or centre-righ (case accidentally VMRO). It is important to notice a permanent place for at least one Albanian party in subsequent governmental coalitions in Macedonia after 1990. The 2000/2001 and the conflict with Albanian minority only intensified this tendency. There are no antisystem political parties. It is a noticeable element of pragmatism in strategy of individual political parties presenting weird electoral coalitions (e.g. socialists in coalition with right-wing ) VMRO. It is possible to differ several phases in forming in Macedonia party system. First phase lasted from 1990 to 1992 and it was characterised by forming of a political stage. The next phase lasted from 1998 and it is possible to describe it as a period of domination of social democratic camp. In the elections of October 1994, the second round of elections was boycotted by VMRO. The period from 1998 to 2001 emerged levelheaded multiparty pluralism with main two groups - centre-leftist SDSM and central-rightist - VMRO. The next period started after Albanian conflict (July 2001), when DUI - a new Albanian group - was formed. Ochrid Agreement strengthened the position of Albanian parties (in Sobranije and also in the local councils). Between 2004 and 2005 there was a process of fragmentarisation of two major Macedonian political parties. New Socialdemocracy broke out from SDSM and National Party broke out from VMRO. But this did not significantly

31 Analizy OSW: Macedonia: Partia rzadzaca wygrywa wybory parlamentarne, www.osw. waw.pl, access: 15 XI 2013. 
weaken those two parties during elections of September 2006. It is possible to observe some regression after the next election in 2008 in the contest between main groups - SDSM and VMRO (they took a "game" form), but international bodies alarmed about threats for functioning a democratic institution.

\section{Bibliography}

\section{Documents, reports, analyzes}

- Konstytucja Republiki Macedonii, wstęp J. Jackowicz, Wydawnictwo Sejmowe, Warszawa 1999.

- "Služben Vesnik na RM", 1994, no. 41.

\section{Monographs}

- Bugajski J., Ethnic politics in Eastern Europe. A Guide to Politics in the Post-Communist Era, ME. Sharpe, New York 2002.

- Koseski A., Macedonia: od republiki zwiazkowej do państwa unitarnego, [in:] A. Koseski, W bałkańskim kręgu, Akademia Humanistyczna im. Aleksandra Gieysztora, Oficyna Wydawnicza Aspra-JR, Pułtusk-Warszawa 2013.

- New political parties of Eastern Europe and the Soviet Union, ed. B. Szajkowski, Harlow, Essex 1991.

- Olszewski P., Macedonia. Historia i wspótczesność, Wyższa Szkoła Handlowa, Radom 2010.

- Polkowska A.M., Macedonia, Agencja Wydawniczo-Reklamowa Alta 2, Wrocław 2000.

- Problemy ewolucji prawa i systemów wyborczych w Polsce i Europie, ed. W. Skrzydło, Wydawnictwo Adam Marszałek, Torun 2012.

- Stawowy-Kawka I., Historia Macedonii, Zakład Narodowy im. Ossolińskich, Wrocław 2000.

\section{Scientific articles and press releases}

- Analizy OSW: Macedonia: Partia rzadzaca wygrywa wybory parlamentarne, www. osw.waw.pl.

- Analizy OSW: Rozpisano wybory przedterminowe w Macedonii, www.osw.waw.pl.

- Balcer A., Albańska kwestia narodowa, [in:] Konflikty etniczne w Europie Środkowej i Potudniowo-Wschodniej, "Zeszyt OSW”, 2002, no. 6.

- Burakowski A., Macedonia, "Europa Środkowo-Wschodnia", 2001-2002, no. 11-12.

- Codogni P., Macedonia, "Europa Środkowo-Wschodnia”, 2005, no. 15.

- Codogni P., Macedonia, "Europa Środkowo-Wschodnia”, 2008, no. 18.

- Darski J., Macedonia-oaza komunistów i pokoju, http://republika.pl.

- Darski J., Prawica w Macedonii, "Gazeta Polska”, 2006, no. 43, 25. 
- Irwin T., Macedonia po 1989 roku, [in:] Polityka Europy Środkowej i PołudniowoWschodniej po 1989 roku, ed. S. P. Ramet, Książka i Wiedza, Warszawa 2012.

- Istorijat na Liberalnata Partija na Makedonija, http:// www.liberalna.org.mk.

- Jackowicz J., Macedonia, “Europa Środkowo-Wschodnia”, 1996, no. 6.

- Jackowicz J., Macedonia, “Europa Środkowo-Wschodnia”, 2000, no. 10.

- Koseski A., Gtówne problemy transformacji w Republice Macedonii. (1991-2000), [in:] Transformacja systemowa państw Europy Wschodniej, Środkowej i Południowej,eds. T. Godlewski, A. Koseski, K.A. Wojtaszczyk, Wyższa Szkoła Humanistyczna im. Aleksandra Gieysztora, Pułtusk 2003.

- Macedonia gotowa jest polec za swa nazwę, "Dziennik”, 11 III 2008.

- Macedonia. Wybory do nowego parlamentu w cieniu starć etnicznych, "Dziennik", 2 VI 2008.

- Osnowanije i razwoj SPM, http://www.spm.com.mk.

- Pawlicki J., Skieterska A., NATO dla Afganistanu, "Gazeta Wyborcza”, 4 IV 2008.

- Perry D., The Republic of Macedonia: finding its way, [in:] Politics, power and struggle for democracy in South-East Europe, ed. K. Dawisha, B. Parrott, Cambridge University Press, Cambridge-New York 1997.

- Pszczółkowska D., Kolejka do NATO jeszcze postoi, “Gazeta Wyborcza”, 7 III 2008.

- Rzegocki P., Macedonia, [in:] Partie i systemy partyjne państw Europy Środkowej $i$ Wschodniej, ed. M. Migalski, Wydawnictwo Wyższej Szkoły Zarządzania i Marketingu, Sosnowiec 2005.

- Skieterska A., Wyborcza przemoc w Macedonii, "Gazeta Wyborcza”, 2 VI 2008.

- Stylińska T., Macedonia czy greckie gadanie, “Tygodnik Powszechny”, 6 IV 2008, no. 14.

- Szpala M., Wybory parlamentarne w Macedonii, „BEST OSW. Tygodnik OSW”, 4. VI 2008, no. 53.

- Umowa koalicyjna w Macedonii, "Dziennik”, 7 VII 2008.

- Żukiewicz P., Przedterminowe wybory w Macedonii w 2011 r. i ich skutki dla konfiguracji macedońskiego systemu partyjnego, "Przegląd Prawa Konstytucyjnego", 2012, no. 2 (10).

Summary: In the formation of the party system in Macedonia one may distinguish some phases. The first phase lasted from 1990 to 1992 and the characteristic of it was the re-formation of the political arena. The next phase lasted to 1998 and it could be described as the period of dominance of social democrats. VMRO boycotted the second poll to the Assembly in October 1994. The candidate of VMRO was defeated in the presidential election. The period of 1998-2001 was the time of sustainable multiparty pluralism with two major parties - central-left-wing SDSM and central-right-wing VMRO. The next phase started after finishing the Alban conflict (July 2001) when the new Alban party was formed - DUI. The period of 2004-2005 led to divisions of two major parties on Macedonian political arena. There were divisions in SDSM (The party of New Social Democrats emerged) and in VMRO (New National Party emerged - VMRO). Still, they did not weaken Macedonian parties during the election to the Assembly in September 2006. After the election in 2008 the regress in the competition between main parties - SDSM and 
VMRO was visible. The win-lose game started in the Macedonian political arena and international organisations alarmed on the dangers of functioning democratic institutions.

Keywords: party system, democratisation, political parties, election, transformation

\section{Formowanie się sceny politycznej Republiki Macedonii}

Streszczenie: W kształtowaniu się systemu partyjnego w Macedonii można wyróżnić kilka faz. Pierwsza faza trwała od 1990 do 1992 roku i charakteryzowała się kształtowaniem sceny politycznej na nowo. Następna faza trwała do 1998 roku i opisać ją można jako okres dominacji obozu socjaldemokratycznego. VMRO zbojkotowała drugą turę wyborów do Zgromadzenia w październiku 1994, jej kandydat przegrał powszechne wybory prezydenckie. Okres lat 1998 i 2001 to zrównoważony pluralizm wielopartyjny, z dwoma głównymi ugrupowaniami: centrolewicowym - SDSM oraz centroprawicowym - VMRO. Kolejny etap rozpoczął się po zakończeniu konfliktu albańskiego (lipiec 2001 roku), gdy uformowało się nowe ugrupowanie albańskie - DUI. Okres lat 2004/2005 zaowocował fragmentaryzacją dwóch głównych ugrupowań macedońskiej sceny politycznej. Nastąpiły wówczas rozłamy w SDSM (powstała Nowa Socjaldemokracja) oraz w VMRO (powstała Partia Narodowa - VMRO). Nie osłabiły one jednak znacząco dwóch wspomnianych partii macedońskich podczas wyborów do Zgromadzenia we wrześniu 2006 roku. Po kolejnej elekcji w 2008 roku można zaobserwować swoisty regres w rywalizacji między głównymi ugrupowaniami - SDSM i VMRO, przybrał on postać swoistej „gry o sumie zerowej", a organizacje międzynarodowe alarmowały o zagrożeniach dla funkcjonowania instytucji demokratycznych.

Słowa kluczowe: system partyjny, demokratyzacja, partie polityczne, wybory, transformacja 